\title{
Stable $\mathrm{Ca}$ and $\mathrm{Sr}$ isotopes indicate biocalcification crisis during OAE1a
}

JIUYUAN WANG*, ANDREW D. JACOBSON, BRADLEY B. SAgEman, MatThew T. Hurtgen

Department of Earth and Planetary Sciences, Northwestern University, Evanston, IL, USA, 60208 (*correspondence: jwang@earth.northwestern.edu)

Large Igneous Province eruptions are expected to trigger biocalcification crises via numerous local-to-global scale mechanisms. The Aptian nannoconid crisis, which correlates with emplacement of the Ontong Java Plateau (OJP) and Ocean Anoxic Event 1a (OAE1a, 120 Ma), may represent one such example [1]. The Ca isotope $\left(\delta^{44 / 40} \mathrm{Ca}\right)$ system offers potential to detect biocalcification fluctuations in the rock record because $\mathrm{Ca}$ isotope fractionation is sensitive to precipitation rate. However, other primary and secondary processes, such as input-output flux perturbations and early diagenesis, can produce similar signals. The stable $\mathrm{Sr}$ isotope $\left(\delta^{88 / 86} \mathrm{Sr}\right)$ system can help resolve the origin of $\delta^{44 / 40} \mathrm{Ca}$ variability because $\mathrm{Sr}$ isotope fractionation is also ratedependent [2], but the proxy appears less prone to diagenetic overprinting [3]. We report high-precision TIMS $\delta^{44 / 40} \mathrm{Ca}$, $\delta^{88 / 86} \mathrm{Sr}$, and ${ }^{87} \mathrm{Sr} /{ }^{86} \mathrm{Sr}$ records for Hole 866A of ODP Leg 143 drilled in Resolution Guyot, mid-Pacific. The samples span from the Barremian ( 127 Ma) to the Albian ( 100 Ma). ${ }^{87} \mathrm{Sr} /{ }^{86} \mathrm{Sr}$ ratios gradually decrease from $\sim 0.70750$ to $\sim 0.70727$, in agreement with the global record. $\delta^{44 / 40} \mathrm{Ca}$ and $\delta^{88 / 86} \mathrm{Sr}$ values range from $-0.74 \%$ to $-1.07 \%$ and $0.25 \%$ to $0.37 \%$, respectively. The $\delta^{44 / 40} \mathrm{Ca}$ and $\delta^{88 / 86} \mathrm{Sr}$ secular trends differ from the ${ }^{87} \mathrm{Sr} /{ }^{86} \mathrm{Sr}$ record, but mimic each other. $\delta^{44 / 40} \mathrm{Ca}$ and [Sr] , as well as $\delta^{44 / 40} \mathrm{Ca}$ and $\delta^{88 / 86} \mathrm{Sr}$, strongly correlate and yield slopes expected for kinetic control $[3,4]$. These results indicate that variable mass-dependent fractionation rather than end-member mixing regulated the isotopic relationship between carbonates and seawater. Positive $\delta^{44 / 40} \mathrm{Ca}$ and $\delta^{88 / 86} \mathrm{Sr}$ shifts within the OAE1a interval are consistent with reduced biocalcification rates. The data support a causal connection between eruption of the OJP and the Aptian nannoconid crisis. Noting that $\left[\mathrm{CO}_{3}{ }^{2-}\right]$ provides a first-order control on precipitation rates, we hypothesize that volcanic $\mathrm{CO}_{2}$ emissions affected the carbonate geochemistry of seawater.

[1] Erba et al. (2010). Science 329, 428-432. [2] Böhm et al. (2012). Geochim. Cosmochim. Acta 93, 300-314. [3] Voigt et al. (2015). Geochim. Cosmochim. Acta 148, 360-377. [4] Tang et al. (2008). Geochim. Cosmochim. Acta 72, 37333745 . 